\title{
Phylogenetic diversity of the endophytic bacterial component of the microbiome of apple clonal rootstocks during in vitro reproduction and cultivation under various agroecological conditions
}

Veronika Bobkova*, Sergey Konovalov, and Mikhail Upadyshev

Federal Horticultural Research Center for Breeding, Agrotechnology and Nursery, 4 str. Zagorievskaja, Moscow, 115598, Russia

\begin{abstract}
The phylogenetic diversity of the endophytic bacterial component of the clonal apple rootstock microbiome 57-490 and 54-118 was studied for microplants and 5-year-old plants grown from the same tissue culture and growing on sod-podzolic soils of different granulometric composition with different chemical, physicochemical and physical properties. Proteobacteria (91.6\%) in rootstock 57-490, Proteobacteria $(52.5 \%)$ and Firmicutes $(47.4 \%)$ in rootstock 54-118 are the predominant phylum of endophytic bacteria in apple rootstock plant tissues in vitro culture. The relative amount of phylum Firmicutes endophytic bacteria, in comparison with in vitro culture, decreases in the roots to $0.7-2.0 \%$, and even more significantly in the leaves (to $0-0.2 \%$ ). At cultivation on heavy loamy soil, endophytic bacteria belonging to the phylum Actinobacteriota $(11.7 \%)$ are found in the studied rootstock roots, the relative content of which, when grown on medium loamy soil, in the roots decreases to $2.7-$ $4.1 \%$, in the leaves - to $0,1-0.2 \%$. The data show that in the endosphere of the culture in vitro, the diversity and uniformity of the community of endophytic bacteria is significantly lower (Shannon index $0.42-1.00)$ than in the roots of rootstocks grown in the outdoor growing (1.34-2.08). For leaves, the Shannon index is characterized by the lowest values $(0.06-$ $0.13)$.
\end{abstract}

\section{Introduction}

Endophytic bacteria are important for the growth, development, fruiting, adaptability of agricultural plants, as they have growth-stimulating, fungicidal and other useful properties [1-2]. The regularities of the formation of the endophytic bacterial component of the microbiome of garden plants at various stages of cultivation - introduction into culture in vitro, during reproduction, when growing in a mother planting, in a nursery, during the cultivation of fruit-bearing garden plantations - have not been sufficiently studied [3-9].

\footnotetext{
*Corresponding author: vstisp.agrochem@yandex.ru
} 
The composition of the endophytic component of the microbiome of different plant tissues of perennial plants differs significantly [4-6, 10-15]. Among 55 isolates of cultivated endophytic bacteria isolated from the roots and leaves of apple varieties in the gardens of Canada [6], half of the bacteria belonged to the Bacillus species, of which 54 inhibited the growth of the apple scab pathogen Venturia inaequalis, and B. megaterium turned out to be the most effective. For the apple tree, the species and quantitative composition of the bacterial component of the microbiome of plant tissues, not only of cultivated varieties, but also of the rootstocks used is of great importance [16]. Highthroughput sequencing of the endophytic bacterial microbiota of tissues of apple plants of varieties Royal Gala, Golden Delicious, Honey Crisp, rootstocks M.9 and MM111 showed [16] that most endophytic bacteria belong to Proteobacteria $(58.4 \%)$, Firmicutes $(23.8 \%)$, Actinobacteria $(7.7 \%)$, Bacteroidetes (2\%) and Fusobacteria $(0.4 \%)$. The rootstocks had little effect on the microbiota of the grafted scion. In closely related cultivars, the microbial community was more similar than in the scion cultivar, which was more distant ingenealogy. The fast growing stock (MM111) had more bacterial taxa to promote growth than the dwarf stock (M.9). Plants, along with microorganisms, function within the optimal range of physicochemical and other parameters of the root zone of the soil; they change the Eh and $\mathrm{pH}$ in the rhizosphere to ensure homeostasis at the cellular level [17, 18]. Therefore, different levels of fertility, redox regime, acid-base and other properties of the soil can affect the patterns of formation of the endophytic bacterial component of the microbiome of garden plants. When assessing the diversity of cultivated bacteria isolated from the roots of apple plants grown in organic and traditional gardens in southern Brazil, it was found [7] that the most numerous genera of bacteria were Enterobacter $(27.7 \%)$, Pseudomonas (18.7 $\%)$, Burkholderia (13.7\%) and Rahnella (12.3\%). Sixty-nine isolates showed antagonistic activity against Colletotrichum gloeosporioides. It was concluded that anthropogenic activity significantly affects the structure of bacterial communities in soil and plant roots.

\section{Materials and methods}

\subsection{Conditions of plant growing}

Research of the taxonomic composition of the bacterial component of the microbiome of plant tissues of clonal rootstocks of apple trees 57-490 and 54-118 were carried out for microplants grown in tissue culture (undifferentiated callus tissue of plant explants 25th passage after introduction into culture in vitro) and on plants of apple rootstocks of 5 years of age, grown from the same tissue culture, and growing in different agroecological conditions, due to different granulometric composition and different chemical, physicochemical and physical properties of sod - podzolic soils of two plots located in Stupinsky (soil of heavy loamy granulometric composition, plot No. 1) and in Leninsky (soil of medium loamy granulometric composition, plot No. 2) districts of the Moscow region.

\subsection{Soil properties}

Plot number 1. Chemical composition of the root layer of heavy loamy soil: alkaline hydrolysable $\mathrm{N}-6.1 \mathrm{mg} / 100 \mathrm{~g}$, mobile $\mathrm{P}_{2} \mathrm{O}_{5}-21.0 \mathrm{mg} / 100 \mathrm{~g}$, mobile $\mathrm{K}_{2} \mathrm{O}-22.0 \mathrm{mg} / 100 \mathrm{~g}$, $\mathrm{CaO}-7.7 \mathrm{mg} / 100 \mathrm{~g}, \mathrm{MgO}-5.4 \mathrm{mg} / 100 \mathrm{~g}$. Physicochemical properties and physical properties of soil: $\mathrm{pH}_{\mathrm{KCl}}-5.4$, redox potential - 280-340 $\mathrm{mV}$, undisturbed soil density $1.38-1.46 \mathrm{~g} / \mathrm{cm}^{3}$. 
Plot number 2. Chemical composition of the root layer of medium loamy soil: alkaline hydrolyzable $\mathrm{N}-9.3 \mathrm{mg} / 100 \mathrm{~g}$, mobile $\mathrm{P}_{2} \mathrm{O}_{5}-66.0 \mathrm{mg} / 100 \mathrm{~g}$, mobile $\mathrm{K}_{2} \mathrm{O}-11.1 \mathrm{mg} / 100 \mathrm{~g}$, $\mathrm{CaO}-12.8 \mathrm{mg} / 100 \mathrm{~g}, \mathrm{MgO}-6.0 \mathrm{mg} / 100 \mathrm{~g}$. Physicochemical properties and physical properties of the soil: $\mathrm{pHKCl}-6.7$, redox potential - $360-520 \mathrm{mV}$, undisturbed soil density $1.23-1.35 \mathrm{~g} / \mathrm{cm}^{3}$.

The chemical, physicochemical and physical properties of the root layer of the soil in plot No. 1 are less favorable for growing apple rootstocks than in plot No. 2.

\subsection{Taxonomic composition of endophytic bacteria}

The study of the taxonomic composition of the bacterial component of the microbiome of plant tissues of apple rootstocks was carried out by the method of high-throughput metagenomic sequencing on the Illumina platform using the equipment of the CUC (Common Use Center)'GenomicTechnologies, Proteomics and Cell Biology' in ARRIAM.

To assess the diversity of communities of the endophytic bacterial component of the microbiome of plant tissues of apple rootstocks, the Shannon and Simpson diversity indices were used [19].

\section{Results and discussion}

The study showed that Proteobacteria (91.6 \%) in rootstock 57-490, Proteobacteria $(52.5$ $\%$ ) and Firmicutes (47.4\%) in rootstock 54-118 are the predominant phylum of endophytic bacteria in plant tissues of apple rootstocks in vitro culture. In the roots and leaves of apple rootstocks growing on sod-podzolic soils, endophytic bacteria of the phylum Proteobacteria prevail (67.7-99.6\%). The relative amount of endophytic bacteria of the phylum Firmicutes, in comparison with in vitro culture, decreases in the roots to $0.7-2.0 \%$, and even more significantly in the leaves (to $0-0.2 \%$ ). At cultivation on heavy loamy soil in the roots of both rootstocks, endophytic bacteria belonging to the phylum Actinobacteriota $(11.7 \%)$ are found, the relative content of which, when grown on medium loamy soil in the roots, decreases to $2.7-4.1 \%$, in leaves - up to $0.1-0.2 \%$. In a less significant relative amount, when grown on soil with different properties, there are representatives of Acidobacteriota (0.5-0.7 \%), Bacteroidota (0.1-2.9 \%), Gemmatimonadota (0.1-0.2\%), Planctomycetota (0.5-1.7 \%), Verrucomicrobiota (0.4-0.5 \%), Myxococcota (0.1-0.6\%), Patescibacteria (0.1\%) (Table 1). 
Table 1. Taxonomic structure (at the phylum level) of endophytic bacteria of plant tissues of apple rootstocks in in vitro culture and at cultivation on soils with different properties, $\%$

\begin{tabular}{|c|c|c|c|c|c|c|c|c|c|c|c|c|c|}
\hline & & $\begin{array}{c}0 \\
0 \\
0 \\
0 \\
0 \\
0 \\
0 \\
0 \\
0 \\
0 \\
0 \\
0\end{array}$ & 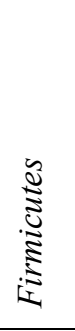 & 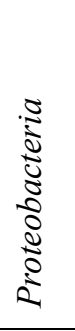 & 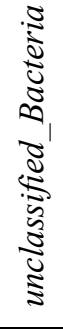 & $\frac{\grave{\Xi}}{\bar{\Xi}}$ & 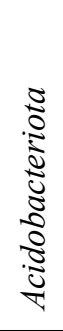 & 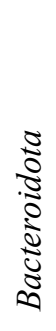 & 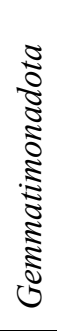 & 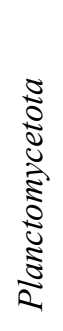 & 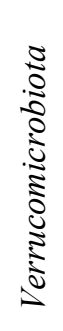 & 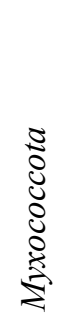 & 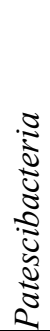 \\
\hline \multicolumn{14}{|c|}{ Rootstock 57-490 } \\
\hline \multicolumn{2}{|l|}{ In vitro } & - & 8.4 & 91.6 & - & - & - & - & - & - & - & - & - \\
\hline \multirow[t]{2}{*}{ Roots } & $\begin{array}{c}\text { Heavy } \\
\text { loam } \\
\text { soil } \\
\end{array}$ & 11.7 & 1.6 & 75.7 & 2.0 & 5.3 & 0.5 & 1.9 & - & 0.5 & 0.5 & 0.1 & 0.1 \\
\hline & $\begin{array}{c}\text { Medium } \\
\text { loam } \\
\text { soil }\end{array}$ & 4.1 & 0.7 & 67.7 & 4.9 & 15.3 & 0.7 & 2.7 & 0.2 & 1.7 & 0.4 & 0.6 & - \\
\hline \multirow[t]{2}{*}{ Leaves } & $\begin{array}{c}\text { Heavy } \\
\text { loam } \\
\text { soil } \\
\end{array}$ & 0.4 & 0.2 & 98.8 & - & 0.4 & - & 0.2 & - & - & - & - & - \\
\hline & $\begin{array}{c}\text { Medium } \\
\text { loam } \\
\text { soil }\end{array}$ & 0.1 & 0.1 & 99.4 & - & 0.3 & - & 0.1 & - & - & - & - & - \\
\hline \multicolumn{14}{|c|}{ Rootstock 54-118 } \\
\hline \multicolumn{2}{|c|}{ In vitro } & 0.1 & 47.4 & 52.5 & - & - & - & - & - & - & - & - & - \\
\hline \multirow[t]{2}{*}{ Roots } & $\begin{array}{l}\text { Heavy } \\
\text { loam } \\
\text { soil } \\
\end{array}$ & 11.7 & 1.6 & 75.7 & 2.0 & 5.3 & 0.5 & 1.9 & - & 0.5 & 0.5 & 0.1 & 0.1 \\
\hline & $\begin{array}{c}\text { Medium } \\
\text { loam } \\
\text { soil }\end{array}$ & 2.7 & 2.0 & 75.6 & 3.6 & 10.3 & - & 2.9 & 0.1 & 0.9 & 0.5 & 0.6 & - \\
\hline \multirow[t]{2}{*}{ Leaves } & $\begin{array}{c}\text { Heavy } \\
\text { loam } \\
\text { soil }\end{array}$ & 0.4 & - & 97.8 & - & 0.1 & - & 0.5 & - & - & - & - & - \\
\hline & $\begin{array}{c}\text { Medium } \\
\text { loam } \\
\text { soil }\end{array}$ & 0.2 & 0.1 & 99.6 & - & - & 0.6 & - & - & - & - & - & - \\
\hline
\end{tabular}

In the leaves of rootstocks, the set of phylum of endophytic bacteria is low: mainly Proteobacteria (up to $99.6 \%$ ), to a lesser extent Actinobacteriota (0.15-0.4 \%), Firmicutes (0-0.2 \%), Acidobacteriota (0-0.6\%), Bacteroidota (0-0.5\%).

Evaluation of the diversity of the main phylum of endophytic bacteria of plant tissues of apple rootstocks by phylogenetic indices indicates that in the endosphere of in vitro culture the diversity and evenness of the community of representatives of the main phylum of endophytic bacteria is significantly lower (Shannon's index 0.42-1.00) than in the roots of rootstocks grown in the open field (1.34-2.08). The obtained values of the Shannon index of the main phylum of endophytic bacteria in plant tissues of apple rootstocks are lower than the values established for other plants [20]. In leaves, the Shannon index is characterized by low values (0.06-0.13), which indicates an insignificant diversity and weak evenness of the number of representatives of the main phyla of endophytic bacteria. In culture in vitro and in plant roots, the values of the Simpson index had similar values $(0.46-0.59)$, but in the 
leaves they increased significantly, which confirms the assumption that representatives of certain few phylum predominate here in the endophytic bacterial community.

At cultivation on medium loamy soil, which has more optimal properties for plants, in both apple rootstocks for roots, the Shannon index took higher values (1.59-2.08) than when grown on heavy loamy soil with worse properties (1.34). This fact indicates a tendency towards a decrease in the diversity and evenness of the endophytic bacterial community in the roots of apple rootstocks when grown on soils with properties less favorable for plants. At the same time, the Simpson index slightly increased on the soil of heavy loamy granulometric composition (0.59) compared to medium loamy soil (0.460.57), which indicates the dominance of roots in the endosphere community with deterioration of conditions for plant growth of certain varieties of endophytic bacteria. For the leaves of apple tree rootstocks, the opposite tendency was observed: under more optimal soil conditions, the diversity and evenness of the endophytic bacterial community in the leaves of apple tree rootstocks decreased (Shannon's index values decreased from 0.11-0.13 to 0.06-0.08). However, the dominance of individual species of endophytic bacteria was growing (the Simpson's index increased from $0.96-0.98$ for a heavy loamy soil to 0.99 for a soil with a medium loamy granulometric composition).

\section{Conclusion}

The study of the phylogenetic diversity of the endophytic bacterial component of the microbiome of clonal rootstocks of apple trees in in vitro culture and plants grown from the same tissue culture and growing on soils with different properties showed that the Proteobacteria and Firmicutes are predominant phylum of endophytic bacteria of plant tissues of apple rootstocks in in vitro culture. The relative amount of endophytic bacteria of the phylum Firmicutes in the roots and, especially, in the leaves is reduced in comparison with the culture in vitro. At cultivation on heavy loamy soil, endophytic bacteria belonging to the phylum Actinobacteriota $(11.7 \%$ ) were found in the roots of the studied rootstocks, the relative content of which, when grown on medium loamy soil, in the roots decreases to 2.7-4.1\%, in the leaves - to $0.1-0.2 \%$. Evaluation of the diversity of the main phylum of endophytic bacteria in plant tissues of apple rootstocks by phylogenetic indices indicates that in the endosphere of an in vitro culture, the diversity and evenness of the community of representatives of the main phylum of endophytic bacteria is significantly lower than in the roots of rootstocks grown in the outdoor growing. In the leaves, there is an insignificant diversity and weak evenness of the abundance of the main phylum of endophytic bacteria.

Acknowledgments. The work was supported by RFBR grant 20-016-00201/21

\section{References}

1. G. Santoyo, G. Moreno-Hagelsieb, C. Orozco-Mosqueda Mdel, B. R. Glick, Microbiol. Res., 183, 92-99 (2016) https://doi.org/10.1016/j.micres.2015.11.008

2. R. Gupta, G. Anand, R. Gaur, D. Yadav, Physiol. Mol. Biol. Plants., 27(1), 165-179 (2021) https://doi.org/10.1007/s12298-021-00927-1

$\begin{array}{llll}\text { 3. I. Miliūtè, O. Buzaitè. Biologija, 57(2), } & \text { 98-102 }\end{array}$ https://doi.org/10.6001/biologija.v57i2.1835

4. I. Miliute, O. Buzaite, D. Baniulis, V. Stanys, Zemdirbyste, 102, 465-478 (2015) http://dx.doi.org/10.13080/z-a.2015.102.060

5. I. Miliute, O. Buzaite, D. Gelvonauskiene, A. Sasnauskas, V. Stanys, D. Baniulis, Zemdirbyste, 103, 77-82 (2016) http://dx.doi.org/10.13080/z-a.2016.103.010 
6. L.E. Muresan, Cultivable Bacterial and Fungal Endophytes from Apple Tissues and Their Potential for Biological Control of Venturia inaequalis, 164 (2017) http://hdl.handle.net/10214/12168

7. J. F. M. Dos Passos, P. B. da Costa, M. D. Costa, G. R. Zaffari, G. Nava, J.I. Boneti, A.M.R. de Oliveira, L.M.P. Passaglia, Genet. Mol. Biol., 37(3), 560-72 (2014) https://doi.org/10.1590/S1415-47572014000400013

8. A. Muthukumar, R. Udhayakumar, R. Naveenkumar, In: D. Maheshwari, K. Annapurna (eds) Endophytes: Crop Productivity and Protection, 133-161 (Springer, Cham., 2017) http://dx.doi.org/10.1007/978-3-319-66544-3_ 7

9. E. Khare, J. Mishra, N.K. Arora, Front. Microbiol., 9, 2732 (2018) https://doi.org/10.3389/fmicb.2018.02732

10. M. Quambusch, J. Brümmer, K. Haller, T. Winkelmann, M. Bartsch, Plant Cell Tiss. Organ Culture, 126(2), 305-317 (2016) https://doi.org/10.1007/s11240-016-0999-0

11. M. Quambusch, A. M. Pirttilä, M. V. Tejesvi, T. Winkelmann, M. Bartsch, Tree Physiol., 34(5), 524-533 (2014) https://doi.org/10.1093/treephys/tpu027

12. I. Tamošiun, G. Stanien, P. Haimi, V. Stanys, R. Rugienius, D. Baniulis, Front. Plant Sci., 9, 889 (2018) https://doi.org/10.3389/fpls.2018.00889

13. S.E. Dunaeva, Yu.S. Osledkin Agr. Biol., 50(1), 3-15 (2015) http://dx.doi.org/10.15389/agrobiology.2015.1.3eng

14. L.S. Samarina, V.I. Malyarovskaya, E.V. Rogozhina, L.S. Malyukova, Agr. Biol., 52 (5), 917-927 (2017)

15. H. Mohamed, A.M. Peterson, A.V. Kozlova, Izv. Sarat. Univ. Chem. Biol. Ecol., 15(3), 80-84 (2015) http://doi.org/10.18500/1816-9775-2015-15-3-80-84

16. J. Liu, A. Abdelfattah, J. Norelli, E. Burchard, L. Schena, S. Droby, M. Wisniewski, Microbiome, 6, 18 (2018) https://doi.org/10.1186/s40168-018-0403-x

17. O. Husson, Plant Soil, 362, 389-417 (2013). https://doi.org/10.1007/s11104-012-1429-7

18. E. Tokarz, D. Urban, J. Ecol. Engin., 16(3), 20-30 (2015) http://dx.doi.org/10.12911/22998993/2801

19. A. E. Magurran, Measuring Biological Diversity, 264 (Blackwell Publ., 2013)

20. Q. Zhang, J.J. Acuña, N.G. Inostroza, M.L. Mora, S. Radic, M.J. Sadowsky, M.A. Jorquera, Sci. Rep., 9, 4950 (2019) https://doi.org/10.1038/s41598-019-41160-X 